\title{
Clinical profile of postpartum cerebral venous thrombosis
}

\author{
Umesh G. Rajoor ${ }^{1 *}$, Seema B. N. $^{2}$ \\ ${ }^{1}$ Department of Medicine, Koppal Institute of Medical Sciences, Koppal, Karnataka, India \\ ${ }^{2}$ Department of Obstetrics and Gynecology, Koppal Institute of Medical Sciences, Koppal, Karnataka, India
}

Received: 07 February 2017

Revised: 09 February 2017

Accepted: 21 February 2017

\author{
*Correspondence: \\ Dr. Umesh G. Rajoor, \\ E-mail: drumeshrajoor@gmail.com
}

Copyright: () the author(s), publisher and licensee Medip Academy. This is an open-access article distributed under the terms of the Creative Commons Attribution Non-Commercial License, which permits unrestricted non-commercial use, distribution, and reproduction in any medium, provided the original work is properly cited.

\begin{abstract}
Background: Pregnancy and puerperium are most prevalent prothrombotic states leading to cerebral venous thrombosis (CVT). Pregnancy induces several changes in coagulation system, which persists at least during early puerperium, rendering it a prothrombotic state. The objective of the study was to study the clinical profile of postpartum CVT.

Methods: A total of 32 consecutive patients admitted in medicine and obstetrics and gynecology ward between April 2012 and March 2015 with radiologically confirmed diagnosis of CVT were included in the study. Detailed history, clinical examination, and laboratory investigations were carried out in all the cases.

Results: Out of 32 patients of CVT studied, the age of patients varied from 18 to 40 years. Maximum incidence was seen in 21-30 age group comprising 74\% of the cases, with mean age being 25.5 years. Two-third of the patients belongs to the low socio-economic class. The majority of them had subacute presentation with the headache in $93.75 \%$, followed by altered sensorium $(90.6 \%)$ and convulsions $(75 \%)$ being the most common presenting symptoms. Radiologically the most common finding noted was hemorrhagic infarction (85.3\%), followed by nonhemorrhagic infarction (15.7\%).
\end{abstract}

Conclusions: Pregnancy and puerperium are most prevalent prothrombotic states leading to CVT.

Keywords: Cerebral venous thrombosis, Prothrombotic, Puerperium

\section{INTRODUCTION}

Although cerebral venous thrombosis (CVT) has been recognised since the early nineteenth century, it is still a disease in which the diagnosis is often overlooked because of the wide variety of clinical presentations, course and outcome. ${ }^{1}$ In young to middle aged adults, CVT is much more common in women than men with a ratio of approximately of $3: 1 .^{2}$ Srinivasan suggested that puerperal CVT is seen more frequent in India compared to western countries. ${ }^{3}$ The reason for this high incidence is not clear. There have been many studies from India on postpartum CVT. The exact pathogenesis of pregnancy associated cerebral venous thrombosis is still unsettled.
Hypercoaguability plays an important role in development of CVT during pregnancy and puerperium. several changes occur in coagulation system, which are more marked during the third trimester, and render it a hypercoaguable state. In addition, dehydration as a result blood loss during delivery and bad obstetric practices and local trauma during delivery worsen the prothrombotic state. The hypercoaguability and venous stasis as a result of prolonged bed rest, instrumental delivery or Caesarean section will lead to thrombosis. Srinivasan in his study stated that puerperal CVT was 10-12 times more frequent in India and the predisposing factors like anaemia, increased coagulability of blood, slowing of the blood stream and dehydration aggravated by the local custom of 
withholding fluid intake in puerperium contributed to the high incidence of CVT. ${ }^{3}$ Alexander et al in their study stated that in patients with pregnancy associated CVT, prothrombotic markers can be multiple and are associated with increased odds of mortality. ${ }^{4}$ In addition to these pathophysiologic processes and factors, several other risk factors have also been noted by various investigators. Caesarean section and infections have been found to be independent risk factors of obstetric CVT and they increase the risk by three times. Caesarean section may increase the risk by postsurgical decline of protein $\mathrm{C}$ levels, presumably because surgically induced tissue damage induces the activation of blood clotting with increased thrombin generation, which in turn both activates protein $\mathrm{C}$ and accelerates its clearance from plasma. Pregnancy induced hypertension and excessive vomiting have also been reported to contribute independently in development of obstetric CVT. Multiparity has been over represented in obstetric CVT from developing countries ${ }^{5}$. The purpose of the present study is to describe the clinical profile and prognosis of postpartum CVT in this part of north Karnataka.

\section{METHODS}

This prospective study was carried out over a period of 3 years between April 2012 to March 2015. Total 32 consecutive patients admitted with pregnancy and puerperium associated CVT confirmed by magnetic resonance imaging (MRI), MR venography, or plain and contrast CT scan were included in the study. Detailed history, clinical examination, and laboratory investigations mentioned below were carried out in all the cases and followed until discharge from the hospital or death. The results were analysed, and descriptive statistics were used. Data were collected by using proforma meeting the objectives of the study. The purpose of the study was carefully explained to the patients and informed consent was taken.

\section{Investigations}

Complete haemogram, blood urea, serum creatinine, serum electrolytes such as sodium, potassium and chloride, urine routine, electrocardiography, chest X-ray, ocular fundoscopy, cerebrospinal fluid analysis and computed tomography scan/magnetic resonance imaging (MRI), magnetic resonance Venogram (MRV) were done.

\section{Statistical Methods}

The results were analysed by calculating percentages, and the mean values.

\section{Statistical Software}

The statistical software namely SPSS 15.0, STATA 8.0, MEDCALC 9.0.1, and SYSTAT 11.0 were used for the analysis of the data and Microsoft word and excel have been used to generate the tables.

\section{RESULTS}

Demographics and baseline characteristics of the patients are depicted in Table 1. Out of 50 patients of CVT studied, the age of patients varied from 18 to 40 years. Maximum incidence was seen in 21-30 age group comprising $74 \%$ of the cases, with the mean age being 25.52 years. The majority of the patients were illiterates $(84 \%)$ and the most of them are from the low socioeconomic state $(75 \%)$.

Table 1: Demographics and baseline characteristics of the patients.

\begin{tabular}{|c|c|c|c|}
\hline \multicolumn{2}{|c|}{ Variables } & \multirow{2}{*}{$\begin{array}{l}\text { No of } \\
\text { patients } \\
25.52\end{array}$} & \multirow[b]{2}{*}{$\%$} \\
\hline Mean age & & & \\
\hline \multirow{3}{*}{$\begin{array}{l}\text { Socioeconomic } \\
\text { status }\end{array}$} & low & 24 & 75 \\
\hline & middle & 07 & 21.8 \\
\hline & high & 01 & 3.2 \\
\hline \multirow{2}{*}{ Literacy } & literate & 05 & 15.7 \\
\hline & iliterate & 27 & 84.3 \\
\hline \multicolumn{4}{|c|}{ Obstetric history } \\
\hline \multirow{3}{*}{ Parity } & Primigravida & 21 & 65.6 \\
\hline & $2^{\text {nd }}$ gravida & 10 & 31.3 \\
\hline & $3^{\text {rd }} / 4^{\text {th }}$ gravida & 01 & 3.1 \\
\hline \multirow{2}{*}{ Period } & Postpartum CVT & 29 & 90.6 \\
\hline & Peripartum CVT & 03 & 9.4 \\
\hline \multirow{2}{*}{ Prenatal care } & Booked & 09 & 28.2 \\
\hline & Unbooked & 23 & 71.8 \\
\hline \multirow{3}{*}{$\begin{array}{l}\text { Mode of } \\
\text { delivery }\end{array}$} & Hospital-vaginal & 20 & \multirow{2}{*}{87.5} \\
\hline & LSCS & 08 & \\
\hline & Home & 04 & 12.5 \\
\hline \multicolumn{4}{|l|}{ Clinical profile } \\
\hline \multirow{7}{*}{ Symptoms } & Headache & 30 & 93.75 \\
\hline & Convulsions & 24 & 75 \\
\hline & $\begin{array}{l}\text { Altered } \\
\text { sensorium }\end{array}$ & 29 & 90.6 \\
\hline & Vomiting & 18 & 56.2 \\
\hline & Focal deficits & 15 & 46.8 \\
\hline & Fever & 12 & 37.5 \\
\hline & Anaemia & 27 & 84.3 \\
\hline \multirow{2}{*}{$\begin{array}{l}\text { Neuroimaging } \\
\text { findings }\end{array}$} & $\begin{array}{l}\text { Haemorrhagic } \\
\text { infarct }\end{array}$ & 27 & 84.3 \\
\hline & $\begin{array}{l}\text { Nonhaemorrhagic } \\
\text { infarct }\end{array}$ & 05 & 15.7 \\
\hline \multirow{2}{*}{ Outcome } & Survived & 32 & 100 \\
\hline & Expired & 00 & 0 \\
\hline
\end{tabular}

CVT was commonly in primigravida $(65.6 \%)$ and in postpartum period $(90 \%)$.

The majority of the patients had subacute presentation with the headache in $93.75 \%$ followed by altered 
sensorium (90.6\%) and convulsions (75\%) being the most common presenting symptoms. All the cases in the present study showed varying degree of consciousness. Anaemia was significantly noted in $84 \%$ of the patients in this study.

The most common neuroimaging finding noted was hemorrhagic infraction $(84.3 \%)$, followed by nonhemorrhagic infraction (15.7\%). Prognosis is good in this study as all $(100 \%)$ the patients recovered well.

\section{DISCUSSION}

Pregnancy and puerperium are well established causes of venous thromboembolism (VTE), including intracranial venous thrombosis. Several physiological changes in coagulation system render pregnancy and puerperium prothrombotic states. Since every woman of reproductive age has potential to become pregnant and hence is at risk of cerebral venous thrombosis (CVT) ${ }^{6-9}$ An attempt is made to study the clinical profile of postpartum CVT in this part of North Karnataka, India.

Majority of the patients in the present study were illiterates $(84.3 \%)$. This may be due to unhygienic health practices like home delivery, local traditional practice of water restriction in the peripartum period, etc. more common among illiterates. M Alexander et al in their study suggested possible role of fluid restriction practice in the causation of CVT and also they noticed that although, this traditional practice is followed even in the hot summer months, there was no increase in the incidence of CVT in the summer months. ${ }^{4}$

Majority of the patients in the present study were in low socio-economic group. This is because the hospital where the study was conducted provides services to the socioeconomic deprived persons. Prakash $\mathrm{C}$ et al in their study mentions that reasons for its frequent occurrence in socioeconomically backward persons especially of Indian origin need to be researched..$^{10}$

Table 2: Comparison of symptomatology with different studies.

\begin{tabular}{|llll|}
\hline $\begin{array}{l}\text { Symptoms } \\
(\%)\end{array}$ & $\begin{array}{l}\text { Nagaraja } \\
\text { D et al } \\
(\mathbf{n = 7 6})\end{array}$ & $\begin{array}{l}\text { Srinivasan } \\
\mathrm{K} \mathrm{et} \mathrm{al}^{3} \\
(\mathbf{n = 1 3 5})\end{array}$ & $\begin{array}{l}\text { Present } \\
\text { study } \\
(\mathbf{n}=50)\end{array}$ \\
\hline Headache & 72 & - & 93.7 \\
\hline Fever & 22 & 15 & 37.5 \\
\hline Seizures & 68 & 68 & 75 \\
\hline $\begin{array}{l}\text { Altered } \\
\text { sensorium }\end{array}$ & 93.4 & 43 & 90.6 \\
\hline Focal deficits & 65.4 & 47.4 & 46.8 \\
\hline Papilloedema & 27 & 15.5 & - \\
\hline
\end{tabular}

The common symptoms noted in the present study are headache (93.7\%) and altered sensorium (90.6\%) and comparable to other studies mentioned in the Table 2 .
The most common neuroimaging finding was haemorrhagic infraction $(84.3 \%)$, followed by nonhaemorrhagic infraction $(15.7 \%)$. Nagaraja et al noted hemorrhagic infraction in $40.9 \%$ and non hemorrhagic infraction in $51.6 \% .^{12}$

Compared to arterial stroke, CVT has favourable outcome. All the patients in the present study have recovered completely. Nagaraja et al, Srinivasan et al and Bansal et al have observed slightly higher percentage of mortality. $3,12,13$ This is probably because these studies involved more number of patients.

\section{CONCLUSION}

Cerebral venous sinus thrombosis is a challenging condition. Diagnosis is frequently overlooked or deferred due to its subacute onset and the wide spectrum of clinical symptoms. Imaging plays a primary role in diagnosis with magnetic resonance imaging (MRI) and magnetic resonance Venogram are diagnostic modality of choice. Prognosis is generally favourable.

Funding: No funding sources

Conflict of interest: None declared

Ethical approval: The study was approved by the Institutional Ethics Committee

\section{REFERENCES}

1. Katrak SM. Cerebral venous thrombosis. Neurological practice: An Indian perspective. Elsevier publications; 2005:336.

2. Bushnell C, Saposnik G. Evaluation and management of cerebral venous thrombosis. Continuum (Minneap Minn), Cerebrovascular Disease. 2014;20(2):335-51.

3. Srinivasan K. Cerebral venous and arterial thrombosis in pregnancy and puerperium: a study of 135 patients. Angiology. 1984;34:731-46.

4. Khealani BA, Mapari UU, Sikandar R. Obstetric Cerebral Venous Thrombosis. J Pak Med Assoc. 2006;56 (11):490-91.

5. Aaron S, Alexander M, Maya T, Mathew V, Goel M, Nair SC, Mammen J, Vikram M. Underlying prothrombotic states in pregnancy associated cerebral venous thrombosis. Neurol India. 2010;58:555-9.

6. National Institutes of health consensus development conference. Prevention of venous thrombosis and pulmonary embolism. JAMA. 1986;256:744-9.

7. Jiann-Shing J, Sung-Chun T, Ping-Keung Y. Stroke in women of reproductive age: comparison between stroke related and unrelated to pregnancy. J Neurol Sci. 2004;221:25-9.

8. Clark P, Brennand J, Conkie JAC, McCall F, Greer IA, Walker ID. Activated protein C sensitivity, protein $\mathrm{C}$, protein $\mathrm{S}$ and coagulation in normal pregnancy. Thromb Haemostas. 1998;79:1166-70. 
9. Cerneca F, Ricci G, Simeone R, Malisano M, Alberico S, Guaschino S. Coagulation and fibrinolysis changes in normal pregnancy. Increased levels of procoagulants and reduced levels of inhibitors during pregnancy induce a hypercoagulable state, combined with a reactive fibrinolysis. Eur J Obstet Gynaecol Reprod Biol. 1997;73:31-6.

10. Prakash C, Bansal BC. Cerebral Venous Thrombosis. J Ind Acad Clin Med. ;5:55-61.

11. Nagaraja D, Taly AB, Das S. Puerperal cerebral venous thrombosis in India. In: Sinha KK, Chandra $\mathrm{P}$, eds. Progress in clinical neurosciences Ranchi. Catholic press. 1989;5:165-177.
12. Nagaraja D, Haridas T, Taly AB, Veerendrakumar M, Subbukrishna DK. Puerperal cerebral venous thrombosis: therapeutic benefit of low dose heparin. Neurol India. 1999;47:43-6.

13. Bansal BC, Gupta RR, Prakash C. Stroke during pregnancy and puerperium in young females below the age of 40 years as a result of cerebral venous sinus thrombosis. Jpn Heart. 1980;21:171-83.

Cite this article as: Rajoor UG, Seema BN. Clinical profile of postpartum cerebral venous thrombosis. Int J Reprod Contracept Obstet Gynecol 2017;6:1192-5. 